OPEN ACCESS

Edited by:

Tetsuji Yamada,

Rutgers University, The State

University of New Jersey,

United States

Reviewed by:

Heath Brandon Mackley,

Penn State Milton S. Hershey Medical

Center, United States

Obrad Zelic

Faculty of Dental Medicine, University

of Belgrade, Serbia

*Correspondence:

Denis Brajkovic

stomatologija@medf.kg.ac.rs

Specialty section:

This article was submitted to

Pharmaceutical Medicine and

Outcomes Research,

a section of the journal

Frontiers in Pharmacology

Received: 16 March 2017

Accepted: 01 June 2017

Published: 16 June 2017

Citation:

Djordjevic G, Dagovic A, Ristic V,

Kanjevac T, Brajkovic D and

Popovic M (2017) Trends and Patterns of Disparities in Oral Cavity and

Pharyngeal Cancer in Serbia:

Prevalence and Economic Consequences in a Transitional

Country. Front. Pharmacol. 8:385. doi: 10.3389/fphar.2017.00385

\section{Trends and Patterns of Disparities in Oral Cavity and Pharyngeal Cancer in Serbia: Prevalence and Economic Consequences in a Transitional Country}

\author{
Gordana Djordjevic ${ }^{1}$, Aleksandar Dagovic ${ }^{2}$, Vladimir Ristic ${ }^{3}$, Tatjana Kanjevac ${ }^{4}$, \\ Denis Brajkovic ${ }^{4 *}$ and Milica Popovic ${ }^{4}$ \\ ${ }^{1}$ Department of Epidemiology, University of Kragujevac, Kragujevac, Serbia, ${ }^{2}$ Department of Clinical Oncology, Faculty of \\ Medical Sciences, University of Kragujevac, Kragujevac, Serbia, ${ }^{3}$ Department of Orthodontics, Faculty of Dentistry, University \\ of Belgrade, Beograd, Serbia, ${ }^{4}$ Department of Dentistry, Faculty of Medical Sciences, University of Kragujevac, Kragujevac, \\ Serbia
}

Keywords: oral carcinoma, prevalence, Europe, risk factors, National Health Programs

\section{EPIDEMIOLOGY OF ORAL CAVITY AND PHARYNGEAL CANCERS}

Oral cavity and pharyngeal cancers (OCPc) encompass malignancies arising in variety of anatomical subsites and are homogeneous regarding epidemiology, clinical presentation, associated risk factors and treatment modalities (Robinson and Macfarlane, 2003; Conway et al., 2006). Worldwide, they are the sixth most common type of cancer, with an estimated 529,500 new cases and 292,300 deaths globally during 2012, accounting for 3,8\% of all cancer cases and 3,6\% of cancer deaths (Ferlay et al., 2015; Shield et al., 2017). The regions with the highest incidence of OCPc include South and Southeast Asia (India, Pakistan, Sri Lanka), Eastern and Western Europe (Hungary, Slovakia, France, Portugal), Latin America (Brazil, Uruguay, Puerto Riko) and the Pacific (Papua New Guinea) (Warnakulasuriya, 2009; Chaturvedi et al., 2013; Weatherspoon et al., 2015). OCPc are the eighth most common cancers among the European countries with an incidence of 73,856 new cases and eleventh leading cause of cancer-related mortality with 34,285 death cases in the year 2012 (Ferlay et al., 2013). In the United States (US), an incidence of 41,380 newly diagnosed patients and 7,890 deaths due to OCPc was reported in 2013 (Weatherspoon et al., 2015). The incidence of OCPc has declined in recent decades in most parts of the world, but has increased in the US, United Kingdom, Australia, Canada, Sweden, Denmark and the Netherlands (Chaturvedi et al., 2013). OCPc are about three times more common in men than women, but this ratio is declining mainly due to increased exposure of women to risk factors (Warnakulasuriya et al., 2015). Recent study showed an increase of the incidence of OCPc for Serbian population for both men and women between 1999 and 2010 (Videnović et al., 2016). Age standardized incidence rates for OCPc for the Serbian population in 2012 were 11,2/100,000, which is lower compared to some European countries (Ferlay et al., 2013). The prevalence for men was 3,5 times higher than for woman, similar to trends in other parts of the Europe (Jankovic et al., 2006; Santric-Milicevic et al., 2009; Ferlay et al., 2013).

\section{OCPc RISK FACTORS}

The traditional risk factors for OCPc are considered tobacco smoking and alcohol consumption, but strong evidences support the infection with high risk human papillomavirus (HPV) types 
16 and 18, as an important causation factor (Marur et al., 2010; Chaturvedi et al., 2011; Radoï and Luce, 2013). Tobacco smoking and alcohol consumption are related to $75 \%$ of OPCc (Shield et al., 2017) and believed to have a synergistic effect (Cunningham et al., 2011). Reduction in smoking worldwide has resulted in significant declines in the incidence of oral cavity cancers in anatomical subsites such as lip, gum, floor of the mouth, hard palate, buccal mucosa, and vestibule (Tota et al., 2017). Evaluation by the International Agency for Research in Cancer (IARC) concluded the carcinogenicity of HPV type 16 in the oral cavity, oropharynx (including tonsil cancer, base of tongue cancer and other oropharyngeal cancer sites), and limited evidence for laryngeal cancer (IACR, 2012). HPV infection is accounted for more than $30 \%$ of OCPc in Northern and Western Europe (De Martel et al., 2012) and more than 60\% in the United States (De Souza et al., 2011), compared to less than $10 \%$ in economically undeveloped countries (Chaturvedi et al., 2013). The incidence of HPV-infected OCPc is as much as 64\% in Serbia (Kozomara et al., 2005). Currently immunization against the most common HPV types is not obligatory in Serbia, although the immunization against HPV type 16 of both men and women can prevent a large proportion of oropharyngeal cancers (IACR, 2012).

Much has been done in the Serbian legislature after 1999 in regards to preventive anti-smoking activities since Serbia had a reputation of having a very high smoking prevalence (Djikanovic et al., 2011). The Serbian health ministry ratified the World Health Organization (WHO) Framework Convention on Tobacco Control (Ministry of Health, 2007). The Law on Protection of Population from Exposure to Tobacco Smoke was passed in the Republic of Serbia in 2010, determining the measures of restricted use of tobacco products (Official Gazette of RS, 2010). However, the results of the National Health Survey in 2013 revealed that the smoking rate had increased by $3 \%$ after the year 2006 (Ministry of Health, 2014). In 2013 34,7\% of the population were smokers with higher prevalence for men, but significant increase in the number of daily women smokers had been observed (Ministry of health 2014). Alcohol drinking in Serbia represents socialy acceptable behavior and alcohol use is a part of tradition and culture (Jakovljevic et al., 2013). According to WHO statistics the drinking pattern in Serbia has been scored 3 on a scale of $1-5$, where 5 represents the riskiest drinking pattern (Jakovljevic et al., 2013).

\section{THE ECONOMIC BURDEN OF CANCER TREATMENT ON SERBIA'S HEALTH SYSTEM}

The Republic of Serbia is a middle-income European country with high unemployment rates and decrease in growth of gross domestic product (GDP) (Santric-Milicevic et al., 2016). The health system in Serbia was based off of the health system of former SFR Yugoslavia, referred to as the Stampar model (Bredenkamp et al., 2011). This system has changed substantially after Yugoslavia's dissolution in the 90's, especially after democratic changes in the 2000 (Jakovljevic and Getzen, 2016; Jakovljevic et al., 2016; Mihailovic et al., 2017). Between
2006 and 2013 health care expenses rose from 9 to $10.4 \%$ GDP (The World Bank, 2016). More than half of public health expenditure is spent on salaries while only $3 \%$ is spent on capital investments and $6 \%$ on preventive health services (SantricMilicevic et al., 2016).

Cancer reporting is obligatory by law in Serbia since 1986 (Miljuš et al., 2010). The Population Register for Cancer was formed in Serbia in 1970, which originated from the Plan of Statistical Research of Interest for the Republic (Official Gazette of the Republic of Serbia No. 32/69). Cancer reports were collected separately by the two cancer registries of Serbia: the Cancer Registry of Central Serbia and the Cancer Registry of Vojvodina (Mihajlović et al., 2013). Until the year 1998, the quality of data collection from these registries was insufficient. But in 1998 they both became members of IACR and the European Network of Cancer Registries which significantly improved the quality of the data (Miljuš et al., 2010).

In the US the 2008 health expenditures in treatment of malignancies reached 77,4 billion dollars (American Cancer Society, 2013) while EU costs for 2009 were 57 billion euros (Luengo-Fernandez et al., 2013). With the worldwide increase in cancer incidence, as well as developments in diagnostic and treatment procedures, these costs will constantly grow (Radovanovic et al., 2011). The burden of malignant diseases in Serbia is enormous (Jakovljevic et al., 2015). In a nationwide population study on Serbian cancer incidence during 19992009 an alarmingly high incidence and mortality compared to European regions was reported (Mihajlović et al., 2013). A rising cancer incidence may be attributed to military conflict in the region, bombardment with depleted uranium during NATO campaigns, post war syndrome and poor socioeconomic parameters (Mihajlović et al., 2013; Kovacević et al., 2015). According to the last edition of the Statistical Yearbook of the Republic of Serbia, 21,865 people died of malignancies in the 2015 (Statistical Office of the Republic of Serbia, 2016).

In Serbia the diagnosis and treatment costs of cancer are dominated by radiotherapy related direct medical costs (Jakovljevic et al., 2015). Direct medical cancer care costs increased by $30 \%$ between 2007 and 2010 with radiotherapy consuming about $54 \%$ of all expenditures (Radovanovic et al., 2011). Regarding palliative cancer treatment the highest expenditures were observed for pharmaceutics (42\%) (Kovacević et al., 2015). Economic recession and domestic policy constraints affected the affordability and quality of cancer treatment for the Serbian population (Dagovic et al., 2015). Lack of national screening programs, insufficient equipment capacities, poor network facilities across rural regions, late diagnosis and palliative care are the main issues to be solved in order to achieve better clinical outcomes and cost-effectiveness of the health care system (Jakovljević, 2013; Dagovic et al., 2015; Jakovljevic et al., 2015, 2017). Due to the economic recession, Serbia faces a migration of medical professionals (specialists, doctors, nurses), which may have potentially disastrous effects on quality of public health system (Santric-Milicevic et al., 2014, 2015, 2016). 


\section{ECONOMICS OF OCPc TREATMENT}

Early diagnosis of OCPc is vital to patient survival (Shield et al., 2017). Only one study assessed the effects of oral cavity cancer screening of high-risk groups, and reported that visual oral examination could reduce mortality by $29 \%$ (Sankaranarayanan et al., 2005). In many cases OCPc are diagnosed at advanced stages, when management is complex and multidisciplinary, and requires prolonged medical care (Hallenbeak et al., 2015). In the North American and European clinical practice, patients with early stage OCPc receive surgical treatment, patients with localy invasive disease are treated with combined treatment modalities (surgery, if indicated + radiotherapy and chemotherapy) while patients with end-stage metastatic disease usually receive palliative chemotherapy (Gold et al., 2009; Chan et al., 2012). Recontructive surgery, medical prostheses and multidisciplinary rehabilitation, follow up care and surveillance are required (Chan et al., 2012; Wissinger et al., 2014).

The full societal burden of cancer treatment consists of associated direct medical expenditures and indirect costs including reduced work force participation, loss of productivity and premature mortality (Wissinger et al., 2014). The existing data on costs associated with OCPc are available from a limited number of socioeconomic studies, mostly from the US and several from Europe. Summarized data from these studies suggest different pattern of expenses since costs associated with OCPc in the US were greatest for systemic therapy, while in the Europe the highest burden of costs was on surgical treatment (Preuss et al., 2007; Diaz-de-Cerio et al., 2013; Wissinger et al., 2014). In 2010 the direct medical costs of head and neck cancer treatment in the US totaled 3.64 billion dollars, which was slightly higher than indirect costs totaled 3.4 billion dollars (Mariotto et al., 2013). The mean per-patient direct medical costs for treatment of head and neck carcinomas in the US totaled 32,500-48,847 dollars, depending on the stage of disease (Wissinger et al., 2014). A report from Greece found that mean direct costs of treatment of OCPc were 7,450 dollars (Zavras et al., 2002). A similar study in the Netherlands reported direct per-patient costs of OCPc treatment of 22,080 dollars (van Agthoven et al., 2001). The main cost burden in patients with advanced disease is the need for multimodal treatments as well as the need for prolonged

\section{REFERENCES}

American Cancer Society (2013). Cancer Facts and Figures 2008. American Cancer Society. Available online at: https://www.cancer.org/research/cancerfacts-statistics/all-cancer-facts-figures/cancer-facts-figures-2008.html

Bredenkamp, C., Mendola, M., and Gragnolati, M. (2011). Catastrophic and impoverishing effects of health expenditure: new evidence from the Western Balkans. Health Policy Plan. 26, 349-356. doi: 10.1093/heapol/ czq070

Chan, A. T., Gregoire, V., Lefebvre, J. L., Licitra, L., Hui, E. P., Leung, S. F., et al. (2012). Nasopharyngeal cancer: EHNS-ESMO-ESTRO Clinical practice guidelines for diagnosis, treatment and follow-up. Ann. Oncol. 23, 83-85. doi: $10.1093 /$ annonc/mds266

Chaturvedi, A. K., Anderson, W. E., Lortet Tieulent, J., Curado, M. P., Ferlay, J., Francheschi, S., et al. (2013). Worldwide trends in incidence rates hospitalization and medical care (Wissinger et al., 2014). The costs of hospitalization of patients with OCPc in the US ranged approximately 20,000-23,000 dollars in 2012 (Le et al., 2013). Regarding the length of hospitalization, the average length of stay in US hospitals for OCPc patients was 16 days (Ryan and Hochman, 2000), considerably lower than in France (29 days) (Pinsolle et al., 1992), The Netherlands (31 days) (van Agthoven et al., 2001) and Greece (34 days) (Zavras et al., 2002). Regarding surgical treatment and defect reconstruction of OCPc, several studies from Europe, the US and Canada compared total costs within the first year of treatment after oral cavity reconstruction with microvascular flaps and local flaps, and observed minimal cost differences (Smeele et al., 2006; Le et al., 2013; Santamarta et al., 2013).

\section{FUTURE IMPLICATIONS TO OCPC PREVENTION}

Although Serbian public health care expenditure is limited due to the recession, slow market recovery since 2013 has resulted with the substantial increase in oncology related public expenditure (Dagovic et al., 2015; Jakovljevic et al., 2015). Currently there are no data on the costs of treatment of OCPc in the Republic of Serbia and there is the need for further research on the budgetary costs. The future national strategies to reduce the prevalence of OCPc should include population health education targeted to reduce exposure to main risk factors: tobacco smoking, alcohol consumption and HPV infection. Promotion and finance of national screening programs, supported by legislure. may be one of the options to reduce cancer treatment costs and obtain more affordable health care.

\section{AUTHOR CONTRIBUTIONS}

All six authors designed the research questions and concept of this opinion article. TK and DB acquired selected published data from the public registry European Health for All Data base issued by WHO. All six authors jointly interpreted the findings stated in the article and contributed important intellectual content to the final manuscript. All six authors checked English spelling and grammar. for oral cavity and oropharyngeal cancers. J. Clin. Oncol. 31, 4550-4558. doi: 10.1200/JCO.2013.50.3870

Chaturvedi, A. K., Engels, E. A., Pfeiffer, R. M., Hernandez, B. Y., Xiao, W., Kim, E., et al. (2011). Human papiloma virus and rising oropharyngeal cancer incidence in the United States. J. Clin. Oncol. 29, 4294-4301. doi: 10.1200/JCO.2011.36.4596

Conway, D. I., Stockton, D. L., Warnakulasuriya, K. A. A. S, Ogden, G., and Macpherson, L. M. D. (2006). Incidence of oral and oropharyngeal cancer in United Kingdom (1990-1999) - recent trends and regional variation. Oral Oncol. 42, 586-592. doi: 10.1016/j.oraloncology.2005.10.018

Cunningham, F. H., Fiebelkorn, S., Johnson, M., and Meredith, C. (2011). A novel application of the Margin of Exposure approach: segregation of tobacco smoke toxicants. Food Chem. Toxicol. 49, 2921-2933. doi: 10.1016/j.fct.2011.07.019

Dagovic, A., Zugic, A., and Jakovljevic, M. (2015). BMacroeconomic policy impact on oncology-related public expenditure in an emerging European 
market - signs of early recovery. Ser. J. Exp. Clin. Res. 16, 43-50. doi: 10.1515/sjecr-2015-0007

De Martel, C., Ferlay, J., Franceschi, S., Vignat, J., Bray, F., Forman, D., et al. (2012). Global burden of cancers attributable to infection in 2008: a review and synthetic analysis. Lancet Oncol. 13, 607-615. doi: 10.1016/s1470-2045(12)70137-7

De Souza, D. L. B., Perez, M. M. B., and Curado, M. P. (2011). Predicted incidence of oral cavity, oropharyngeal, laryngeal and hypopharyngeal cancer in Spain and implications for cancer control. Cancer Epidemiol. 35, 510-514. doi: 10.1016/j.canep.2011.02.012

Diaz-de-Cerio, P., Preciado, J., Santaolalla, F., and Sanchez-Del-Rey, A. (2013). Cost-minimisation and cost-effectiveness analysis comparing transoral CO laser cordectomy, laryngofissure cordectomy and radiotherapy for the treatment of T1-2, N0, M0 glottic carcinoma. Eur. Arch. Otorhinolaryngol. 270, 1181-1188. doi: 10.1007/s00405-012-2139-8

Djikanovic, B., Marinkovic, J., Jankovic, J., Vujanac, V., and Simic, S. (2011). Gender differences in smoking experience and cessation: do wealth and education matter equally for women and men in Serbia? J. Public Health 33, 31-38. doi: 10.1093/pubmed/fdq080

Ferlay, J., Soerjomataram, I., Dikshit, R., Eser, S., Mathers, C., Rebelo, M., et al. (2015). Cancer incidence and mortality worldwide: sources, methods and major patterns in GLOBOCAN 2012. Int. J. Cancer 136, E359-E386. doi: $10.1002 /$ ijc. 29210

Ferlay, J., Steliarova-Foucher, E., Lortet-Tieulent, J., Rosso, S., Coebergh, J. W. W., Comber, H., et al. (2013). Cancer incidence and mortality patterns in Europe: estimates for 40 countries in 2012. Eur. J. Cancer 49, 1374-1403. doi: 10.1016/j.ejca.2012.12.027

Gold, K. A., Lee, H. Y., and Kim, E. S. (2009). Targeted therapies in squamous cell carcinoma of the head and neck. Cancer 115, 922-935. doi: 10.1002/cncr.24123

Hallenbeak, C. S., Kulaylat, A. N, Mackley, H., Koch, W., Schaefer, E. W., and Goldenberg, D. (2015). Determinants of Medicare costs for elderly patients with oral cavity and pharyngeal cancers. JAMA Otolaryngol. Head Neck Surg. 141, 628-635. doi: 10.1001/jamaoto.2015.0940

IACR. (2012). IARC Monographs on the Evaluation of Carcinogenic Risks to Humans. Volume 100B. International Agency for Research on Cancer. Available online at: http://monographs.iarc.fr/eng/monographs/vol100b/ mono100b-11.pdf. (Assessed April 17, 2017. B)

Jakovljević, M. B. (2013). Resource allocation strategies in Southeastern European health policy. Eur. J. Health Econ. 14, 153-159. doi: 10.1007/s10198-012-0439-y

Jakovljevic, M., and Getzen, T. E. (2016). Growth of global health spending share in low and middle income countries. Front. Pharmacol. 7:21. doi: 10.3389/fphar.2016.00021

Jakovljevic, M, Lazarevic, M, Milovanovic, O, and Kanjevac, T. (2016). The new and old Europe: east-west split in pharmaceutical spending. Front. Pharmacol. 7:18. doi: $10.3389 /$ fphar.2016.00018

Jakovljevic, M., Malmose-Stapelfeldt, C., Milovanovic, O., Rancic, N., and Bokonjic, D. (2017). Disability, work absenteeism, sickness benefits, and cancer in selected European OECD countries-forecasts to 2020. Front. Public Health 5:23. doi: $10.3389 /$ fpubh.2017.00023

Jakovljevic, M., Riegler, A., Jovanovic, M., Djordjevic, N., Patek, K., Lesch, O., et al. (2013). Serbian and Austrian alcohol-dependent patients: a comparison of two samples regarding therapeutically relevant clinical features. Alcohol Alcohol. 48, 505-508. doi: 10.1093/alcalc/agt011

Jakovljevic, M., Zugic, A., Rankovic, A., and Dagovic, A. (2015). Radiation therapy remains the key cost driver of oncology inpatient treatment. J. Med. Econ. 18, 29-36. doi: 10.3111/13696998.2014.971162

Jankovic, S., Vlajinac, H., Bjegovic, V., Marinkovic, J., Sipetic-Grujicic, S., Markovic-Denic, L., et al. (2006). The burden of disease and injury in Serbia. Eur. J. Public Health 17, 80-85. doi: 10.1093/eurpub/ckl072

Kovacević, A., Dragojević-Simić, V., Rancić, N., Jurisević, M., Gutzwiller, F. S., Matter-Walstra, K., et al. (2015). End-of-life costs of medical care for advanced stage cancer patients. Vojnosanit. Pregl. 72, 334-341. doi: 10.2298/VSP1504334K

Kozomara, R., Jović, N., Magić, Z., Branković-Magić, M., and Minić, V. (2005). p53 mutation and human papillomavirus in oral squamous cell carcinomas: correlation with overall survival. J. Craniomaxillofac. Surg. 33, 342-348. doi: $10.1016 /$ j.jcms.2005.05.004
Le, R., Fakhry, C., Koch, W. M., and Gourin, C. G. (2013). The effect of tumor subsite on short-term outcomes and costs of care after oral cancer surgery. Laryngoscope 123, 1652-1659. doi: 10.1002/lary.23952

Luengo-Fernandez, R., Leal, J., Gray, A., and Sullivan, R. (2013). Economic burden of cancer across the European Union: a populationbased cost analysis. Lancet Oncol. 14, 1165-1174. doi: 10.1016/s1470-2045(13)70442-x

Mariotto, A. B., Yabroff, K. R., Shao, Y., Feuer, E. J., and Brown, M. L. (2013). Projections of the cost of cancer care in the United States: 2010-2020. J. Natl. Cancer Inst. 103, 117-128. doi: 10.1093/jnci/djq495

Marur, S. D, Souza, G., Westra, W. H., and Forastiere, A. A. (2010). HPV associated head and neck cancer: a virus related cancer epidemic. Lancet Oncol. 11, 781-789. doi: 10.1016/S1470-2045(10)70017-6

Mihailovic, N. M., Kocic, S. S., Trajkovic, G., and Jakovljevic, M. (2017). Satisfaction with Health Services among the Citizens of Serbia. Front. Pharmacol. 8:50. doi: 10.3389/fphar.2017.00050

Mihajlović, J., Pechlivanoglou, P., Miladinov-Mikov, M., Zivković, S., and Postma, M. J. (2013). Cancer incidence and mortality in Serbia 1999-2009. BMC Cancer 13:18. doi: 10.1186/1471-2407-13-18

Miljuš, D., Vukičević, A., and Živković, S. (2010). Cancer Incidence and Mortality in Central Serbia (1999-2007). Belgrade: Cancer Registry of Serbia, Institute of Public Health of Serbia "Dr Milan Jovanović-Batut." Available online at: http://www.batut.org.rs/download/publikacije/Health\%20of\%20population \%201997-2007.pdf

Ministry of Health Republic of Serbia (2007). Tobacco Control Strategy of the Republic of Serbia. Official Gazette Republic of Serbia 8/07. Available online at https://www.tobaccocontrollaws.org/files/live/Serbia/Serbia $\% 20 \% 20$ Tobacco\%20Control\%20Strategy.pdf

Ministry of Health of Republic of Serbia (2014). Results of National Health Survey 2013. Key Findings. Available online at: http://www.batut.org.rs/download/ publikacije/2013SerbiaHealthSurvey.pdf

Official Gazette of RS (2010). Law on Protection of the Population from Exposure to Tobacco Smoke, No. 30/2010. Available online at: http://www.batut.org.rs/download/publikacije/2013SerbiaHealthSurvey.pdf

Pinsolle, J., Demaux, H., Coustal, B., Siberchichot, F., Caudry, M., Maire, J. P., et al. (1992). Results of surgical treatment of T3 and T4 tumors of the oral cavity and pharynx. Am. J. Surg. 164, 587-591. doi: 10.1016/S0002-9610(05)80712-3

Preuss, S. F., Quante, G., Semrau, R., Mueller, R. P., Klussmann, J. P., and Guntinas-Lichius, O. (2007). An analysis of surgical complications, morbidity, and cost calculation in patients undergoing multimodal treatment for operable oropharyngeal carcinoma. Laryngoscope 117, 101-105. doi: 10.1097/01.mlg.0000246191.90021.5e

Radoï, L., and Luce, D. (2013). A review of risk factors for oral cavity cancer: the importance of a standardized case definition. Community Dent. Oral Epidemiol. 41, 97-109. doi: 10.1111/j.1600-0528.2012.00710.x

Radovanovic, A., Dagovic, A., and Jakovljevic, M. (2011). Economics of cancer related medical care: world wide estimates and available domestic evidence. Arch. Oncol. 19, 59-63. doi: 10.2298/AOO1104059R

Robinson, K. L., and Macfarlane, G. J. (2003). Orapharyngeal cancer incidence and mortality in Scotland: are rates still increasing? Oral Oncol. 39, 31-36. doi: 10.1016/S1368-8375(02)00014-3

Ryan, M. W., and Hochman, M. (2000). Length of stay after free flap reconstruction of the head and neck. Laryngoscope 110, 210-216. doi: 10.1097/00005537-200002010-00005

Sankaranarayanan, R., Ramadas, K., and Thomas, G. (2005). Effect of screening on oral cancer mortality in Kerala, India: a cluster-randomised controlled trial. Lancet 365, 1927-1933. doi: 10.1016/S0140-6736(05)66658-5

Santamarta, T. R., de Villalain, L., Pena, I., Fernandez-del Valle, A., Megias, J., and de Vicente, J. C. (2013). Comparative study of locoregional flaps and free flaps in reconstruction after resection of oral cavity cancer: a cost analysis. Oral Oncol. 49, S114. doi: 10.1016/j.oraloncology.2013.03.302

Santric-Milicevic, M., Bjegovic, V., Terzic, Z., Vukovic, D., Kocev, N., Marinkovic, J., et al. (2009). Serbia within the European context: an analysis of premature mortality. Popul. Health Metr. 7:12. doi: 10.1186/1478-7954-7-12

Santric-Milicevic, M., Matejic, B., Terzic-Supic, Z., Vasic, V., Babic, U., and Vukovic, V. (2015). Determinants of intention to work abroad of college and specialist nursing graduates in Serbia. Nurse Educ. Today 35, 590-596. doi: 10.1016/j.nedt.2014.12.022 
Santric-Milicevic, M. M., Terzic-Supic, Z. J., Matejic, B. R., Vasic, V., and Ricketts, T. C. (2014). First- and fifth-year medical students' intention for emigration and practice abroad: a case study of Serbia. Health Policy 118, 173-183. doi: 10.1016/j.healthpol.2014.09.018

Santric-Milicevic, M., Vasic, V., and Terzic-Supic, Z. (2016). Do health care workforce, population, and service provision significantly contribute to the total health expenditure? An econometric analysis of Serbia. Hum. Resour. Health 14, 50-57. doi: 10.1186/s12960-016-0146-3

Shield, K. D., Ferlay, J., Jemal, A., Sankaranarayanan, R., Chaturvedi, A. K., Bray, F., et al. (2017). The Global incidence of lip, oral cavity, and pharyngeal cancers by subsite in 2012. CA Cancer J. Clin. 67, 51-64. doi: 10.3322/caac.21384

Smeele, L. E., Goldstein, D., Tsai, V., Gullane, P. J., Neligan, P., Brown, D. H., et al. (2006). Morbidity and cost differences between free flap reconstruction and pedicled flap reconstruction in oral and oropharyngeal cancer: matched control study. J. Otolaryngol. 35, 102-107. doi: 10.2310/7070.2005.5001

Statistical Office of the Republic of Serbia (2016). Statistical Yearbook of the Republic of Serbia. Available online at: http://pod2.stat.gov.rs/ ObjavljenePublikacije/G2016/pdf/G20162019.pdf

The World Bank (2016). Health Expenditure, Total (\% of GDP). Available online at: http://data.worldbank.org/indicator/SH.XPD.TOTL.ZS

Tota, J. E., Anderson, W. F., Coffey, C., Califano, J., Cozen, W., Ferris, R. L., et al. (2017). Rising incidence of oral tongue tongue cancer among white men and women in the United States, 1973-2012. Oral Oncol. 67, 146-152. doi: 10.1016/j.oraloncology.2017.02.019

van Agthoven, M., van Ineveld, B. M., de Boer, M. F., Leemans, C. R., Knegt, P. P., Snow, G. B., et al. (2001). The costs of head and neck oncology: primary tumours, recurrent tumours and long-term follow-up. Eur. J. Cancer 37, 2204-2211. doi: 10.1016/s0959-8049(01)00292-1

Videnović, G., Ilić, D., Miljus, D., Krasić, D., Vlahović, Z., Zivković, S., et al. (2016). Lip, oral cavity and pharyngeal cancers in the population of the city of Belgrade in the period 1999-2010. Vojnosanit. Pregl. 73, 53-58. doi: 10.2298/VSP141112023V
Warnakulasuriya, S. (2009). Global epidemiology of oral and oropharyngeal cancer. Oral Oncol. 45, 309-316. doi: 10.1016/j.oraloncology.2008.06.002

Warnakulasuriya, S., Fennell, N., Diz, P., Seoane, J., and Rapidis, A. (2015). An appraisal of oral cancer and pre-cancer screening programmes in Europe: a systematic review. J. Oral Pathol. Med. 44, 559-570. doi: 10.1111/jop. 12267

Weatherspoon, D. J., Chattopadhyay, A., Boromand, S., and Garcia, I. (2015). Oral cavity and oropharyngeal cancer incidence trends and disparities in the United States: 2000-2010. Cancer Epidemiol. 39, 497-504. doi: 10.1016/j.canep.2015.04.007

Wissinger, E., Griebsch, I., Lungershausen, J., Foster, T., and Pashos, C. L. (2014). The economic burden of head and neck cancer: a systematic literature review. Pharmacoeconomics 32, 865-882. doi: 10.1007/s40273-014-0169-3

Zavras, A., Andreopoulos, N., Katsikeris, N., Zavras, D., Cartsos, V., and Vamvakidis, A. (2002). Oral cancer treatment costs in Greece and the effect of advanced disease. BMC Public Health 2:12. doi: 10.1186/1471-2458-2-12

Conflict of Interest Statement: The authors declare that the research was conducted in the absence of any commercial or financial relationships that could be construed as a potential conflict of interest.

The reviewer OZ declared a shared affiliation, though no other collaboration, with one of the authors VR to the handling Editor, who ensured that the process nevertheless met the standards of a fair and objective review.

Copyright (c) 2017 Djordjevic, Dagovic, Ristic, Kanjevac, Brajkovic and Popovic. This is an open-access article distributed under the terms of the Creative Commons Attribution License (CC BY). The use, distribution or reproduction in other forums is permitted, provided the original author(s) or licensor are credited and that the original publication in this journal is cited, in accordance with accepted academic practice. No use, distribution or reproduction is permitted which does not comply with these terms. 